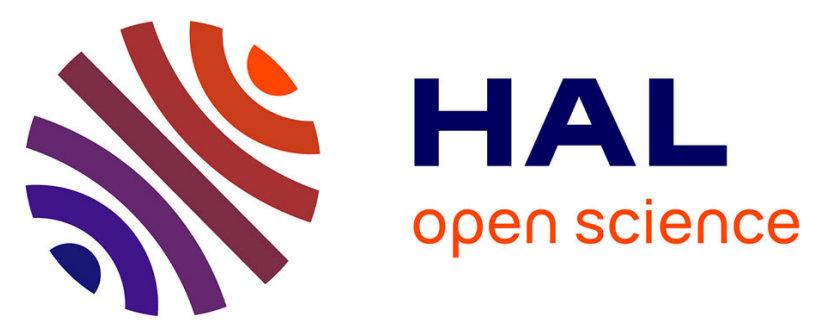

\title{
Monoclonal antibody N-glycosylation profiling using capillary electrophoresis - Mass spectrometry: Assessment and method validation
}

Jeremie Giorgetti, Valentina D'atri, Julie Canonge, Antony Lechner, Davy Guillarme, Olivier Colas, Elsa Wagner-Rousset, Alain Beck, Emmanuelle Leize-Wagner, Yannis-Nicolas François

\section{To cite this version:}

Jeremie Giorgetti, Valentina D'atri, Julie Canonge, Antony Lechner, Davy Guillarme, et al.. Monoclonal antibody N-glycosylation profiling using capillary electrophoresis - Mass spectrometry: Assessment and method validation. Talanta, 2018, 178, pp.530-537. 10.1016/j.talanta.2017.09.083 . hal-01981307

\section{HAL Id: hal-01981307 https://hal.science/hal-01981307}

Submitted on 14 Jan 2019

HAL is a multi-disciplinary open access archive for the deposit and dissemination of scientific research documents, whether they are published or not. The documents may come from teaching and research institutions in France or abroad, or from public or private research centers.
L'archive ouverte pluridisciplinaire $\mathbf{H A L}$, est destinée au dépôt et à la diffusion de documents scientifiques de niveau recherche, publiés ou non, émanant des établissements d'enseignement et de recherche français ou étrangers, des laboratoires publics ou privés. 


\section{Monoclonal Antibody N-Glycosylation Profiling using Capillary Electrophoresis - Mass Spectrometry: Assessment and Method Validation.}

Jérémie Giorgetti ${ }^{1}$, Valentina D'Atri ${ }^{2}$, Julie Canonge ${ }^{1}$, Antony Lechner ${ }^{1}$, Davy Guillarme ${ }^{2}$, Olivier Colas ${ }^{3}$, Elsa Wagner-Rousset ${ }^{3}$, Alain Beck ${ }^{3}$, Emmanuelle Leize-Wagner ${ }^{1}$, YannisNicolas François ${ }^{1}$

\footnotetext{
${ }^{1}$ Laboratoire de Spectrométrie de Masse des Interactions et des Systèmes (LSMIS) UMR 7140 (Unistra-CNRS), Université de Strasbourg, France.

2 School of Pharmaceutical Sciences, University of Geneva, University of Lausanne, Centre Médical Universitaire (CMU) - Rue Michel-Servet 1, 1206 Geneva , Switzerland

${ }^{3}$ Centre d'immunologie Pierre Fabre; Saint-Julien-en-Genevois, France.
}

\section{ABSTRACT:}

Characterization of therapeutic proteins represents a major challenge for analytical sciences due to their heterogeneity caused by post-translational modifications (PTM). Among these PTM, glycosylation which is possibly the most prominent, require comprehensive identification because of their major influence on protein structure and effector functions of monoclonal antibodies (mAbs). As a consequence, glycosylation profiling must be deeply characterized. For this application, several analytical methods such as separation-based or MS-based methods, were evaluated. However, no CEESI-MS approach has been assessed and validated. Here, we illustrate how the use of CE-ESI-MS method permits the comprehensive characterization of $\mathrm{N}$-glycosylation of $\mathrm{mAbs}$ at the glycopeptide level. Validation of the CE-ESI-MS method in terms of robustness and reproducibility was demonstrated through the relative quantitation of glycosylation profiles for ten different mAbs produced in different cell lines. Glycosylation patterns obtained for each mAbs were compared to Hydrophilic Interaction Chromatography of 2-aminobenzamide labeled glycans with fluorescence detector (HILIC-FD) analysis considered as a reference method. Very similar glycoprofiling were obtained with the CE-ESI-MS and HILIC-FD demonstrating the attractiveness of CE-ESI-MS method to characterize and quantify the glycosylation heterogeneity of a wide range of therapeutic mAbs with high accuracy and precision.

Keywords: Capillary Electrophoresis-Mass spectrometry; Monoclonal antibody; IgG glycosylation; HILIC-FD; Glycopeptide 
Monoclonal antibodies (mAbs) were introduced for the treatment of various diseases in the late 1980 and they still represent the most rapidly growing category of therapeutic molecules today [1-3]. mAbs are particularly interesting because of their good therapeutic efficiency, favorable pharmacokinetic and pharmacodynamics, and relatively low side-effects [4]. mAbs are tetrameric glycoproteins having a molecular mass of approximately $150 \mathrm{kDa}$, composed of two heavy chains and two light chains, interlinked by several disulfide bonds, and having at least one conserved $\mathrm{N}$-glycosylation site located in the Fc domain [3]. Glycosylation is a post-transcriptional modification (PTM) that occurs naturally during excretion of antibodies from the expression system to the extracellular medium. It only represents 2$5 \%$ of the total mass of the protein but it is subjected to extensive studies due to its significant influence on effector functions of mAbs, especially antibody-dependent cell-mediated cytotoxicity (ADCC) and complement-dependent cytotoxicity (CDC) [5-8]. As a consequence, the mAbs glycosylation profile is considered as a critical quality attribute (CQA) and must be thoroughly analyzed [9-13]. The complexity and heterogeneity of the glycosylation pattern is mainly due to mAbs production in living expression systems [14-16] and requires a number of orthogonal analytical techniques to be fully characterized. Several analytical methods have been described for the glyco-variants characterization at different levels (from released glycans to intact protein level) including separative techniques (liquid chromatography (LC), capillary electrophoresis (CE)) often coupled to spectrometric, amperometric and mass spectrometric detection [17-21]. Recently, Reusch's group published two major articles dealing with the analysis of Fc-glycosylation profiles, and comparing several separation methods hyphenated or not with mass spectrometry (MS) detection [20-21]. This comprehensive comparison showed an excellent precision and accuracy for all the methods. However, concerning MS-based methods [22-25], a large panel of methodologies were evaluated, except the CE-ESI-MS approach. Nevertheless, in 2008, Gennaro et al. described the development of CE-ESI-MS technology with online LIF detection that allows identification of major and minor glycan species observed in the routine CELIF assay. Despite significant instrumental development to achieve LIF and MS dual detection, their strategies allowed to perform quantitative analysis provided by the on-line LIF trace and to increase confidence by providing accurate mass information [26]. More recently, Gahoual et al. reported the development of CE-ESI-MS technique for the characterization of the primary structure of mAbs performed in a single injection [27]. Based on a bottom-up approach, they highlighted the benefits of using electrophoretic separation in complement to chromatographic separation, which is conventionally applied in this type of study. CE separation selectivity allowed to simultaneously perform the amino acid sequencing and the PTMs characterization, including the $\mathrm{N}$-glycosylation profiling. However, concerning the latter point, the approach was not statistically validated and 
potential bias in the obtained glycosylation heterogeneity could exist [28]. In the meantime, Heemskerk et al. reported the use of a similar methodology for highly sensitive IgG1 glycosylation profiling as a complementary method to a high-throughput nano-RPLC-MS [29]. They concluded that CE-ESI-MS provide information on IgG Fc glycosylation with concentrations below the LODs of the conventional methods. However, no comparison with reference method were applied to validate the obtained glycosylation heterogeneity.

In this report, we evaluated and validated CE-ESI-MS method to characterize and quantify the heterogeneity of the glycosylation pattern with high accuracy, precision and robustness. A systematic characterization study of glycovariants obtained from ten different therapeutic mAbs produced in different expression systems ( $\mathrm{CHO}, \mathrm{NSO}$ and SP2/0), has been performed to evaluate the suitability of CE-ESI-MS method, according to mAbs properties. Rituximab (chlgG1, CHO), palivizumab (hzlgG1, $\mathrm{SP2} / 0$ ), natalizumab (hzlgG4, NSO), nivolumab (hulgG4, CHO), trastuzumab (hzlgG1, CHO), panitumumab (hulgG2, CHO), adalimumab (hulgG1, CHO), infliximab-Remicade ${ }^{\circledR}$ (chlgG1, SP2/0) as well as two infliximab biosimilars, infliximab-Inflectra ${ }^{\circledR}$ (chlgG1 SP2/0) and infliximab-remsima ${ }^{\circledR}$ (chlgG1 SP2/0), were selected for this study. Comparison with glyco-profiling of released and 2-AB labeled glycans (used as a reference method) obtained by state-of-the-art Hydrophilic Interaction Chromatography (HILIC) was methodically performed to assess the reliability of the CE-ESI-MS methodology. (1)

\section{Experimental}

2.1. Chemicals. Chemicals used were of analytical grade or high purity grade and purchased from Sigma-Aldrich (Saint Louis, MO, USA). Water used to prepare buffers and sample solutions was obtained using an ELGA purelab UHQ PS water purification system (Bucks, UK). RapiGest SF surfactant was purchased from Waters (Milford, MA, USA). mAbs and biosimilars products were all kindly provided by Pierre Fabre laboratories (Saint-Julien en Genevois, France).

2.2. Sample preparation. A volume corresponding to $100 \mu \mathrm{g}$ of protein was used. Samples were first diluted from stock solution to a concentration of $45.6 \mu \mathrm{M}$ by using milliQ water. A second dilution to a concentration of $22.2 \mu \mathrm{M}$ was performed by using $0.1 \%$ RapiGest surfactant and incubation at $40^{\circ} \mathrm{C}$ for $10 \mathrm{~min}$. Reduction of the samples was then achieved by the addition of dithiothreitol (DTT, final concentration of $25 \mathrm{mM}$ ) and incubation at $95^{\circ} \mathrm{C}$ for $5 \mathrm{~min}$. Once cooled down to room temperature (RT), the alkylation of the cysteines (Cys) was performed to avoid the reformation of the disulphide bonds. Thus, iodoacetamide (IDA, final concentration of $10 \mathrm{mM}$ ) was added to the samples, followed by incubation at RT for $20 \mathrm{~min}$ in the dark. For performing the trypsin digestion, a volume of $1 \mu \mathrm{L}$ of 
$100 \operatorname{trypsin}(0.5 \mu \mathrm{g} / \mu \mathrm{L})$ was added to the samples that were left at room temperature for $3 \mathrm{~h}$. Then another 101 volume of $1 \mu \mathrm{L}$ was added afterward and digestion was performed overnight at $37^{\circ} \mathrm{C}$. In order to cleave 102 the surfactant, formic acid (FA) was added to the samples at a final concentration of $1 \%(\mathrm{v} / \mathrm{v})$ and 103 samples were left at RT for $2 \mathrm{~h}$. Samples were finally diluted to a final protein concentration of $2.2 \mu \mathrm{M}$ 104 using ammonium acetate $50 \mathrm{mM}(\mathrm{pH} 4.0)$.

105 2.3. Capillary electrophoresis. The CE experiments were performed with a CESI8000 capillary 106 electrophoresis system from Sciex Separation (Brea, CA, USA). A 32 Karat $^{\mathrm{TM}}$ (Sciex Separation) was used 107 for instrument control, data acquisition and data handling. Bare fused-silica capillaries (total length 100 $108 \mathrm{~cm} ; 30 \mu \mathrm{m}$ i.d.) with characteristic $3 \mathrm{~cm}$ porous tip on its final end, a second capillary (total length 80 $109 \mathrm{~cm} ; 50 \mu \mathrm{m}$ i.d.) filled during experiments with BGE allows electric contact. New capillaries were flushed 110 for $10 \mathrm{~min}$ at $75 \mathrm{psi}$ (around 5 bar) with methanol, then $10 \mathrm{~min}$ with $0.1 \mathrm{M}$ sodium hydroxide, followed 111 by $10 \mathrm{~min}$ with $0.1 \mathrm{M}$ hydrochloric acid and water for $20 \mathrm{~min}$ at $75 \mathrm{psi}$. Finally, the capillary was flushed 11210 min at 75 psi with BGE which contains 10\% acetic acid. Hydrodynamic injection (6 psi for 2 min) 113 corresponding to a total volume of $90 \mathrm{~nL}$ of injected sample was used. Injection volumes were 114 calculated by using the CEToolbox application (Pansanel, GooglePlay). Separations were performed 115 using a voltage of $+20 \mathrm{kV}$.

116 2.4. Mass spectrometry. For glycopeptide analysis, the CESI system was hyphenated with a 5600 117 TripleTOF mass spectrometer (Sciex, Darmstadt, Germany). The MS instrument is equipped with a 118 hybrid analyzer composed of quadrupoles followed by a time-of-flight (TOF) analyzer. ESI source 119 parameters were set as follows: ESI voltage $-1.75 \mathrm{kV}$, gas supplies (GS1 and GS2) were deactivated, 120 source heating temperature $150^{\circ} \mathrm{C}$ and curtain gas value 5. Experiments were performed in Top 15 121 information dependent acquisition (IDA), accumulation time was $250 \mathrm{msec}$ for MS scans and $100 \mathrm{msec}$ 122 for MS/MS scans leading to a total duty cycle of $1.75 \mathrm{sec}$. Mass/charge (m/z) range was set to 100-2000 123 in MS and 50-2000 in MS/MS. Using those parameters, the mean resolution provided by the instrument 124 is 40000 in MS (for $\mathrm{m} / \mathrm{z} 485.251$ ) and 25000 in MS/MS (for $\mathrm{m} / \mathrm{z}$ 345.235).

125 2.5. MS/MS data analysis. Data obtained from the sheathless CE-MS/MS experiments were analyzed 126 using Peakview software (Sciex, San Francisco, CA). The allowed mass tolerance for search algorithm 127 identification, were set to $\pm 5 \mathrm{ppm}$ and \pm 0.05 Da for precursor ions and fragmentation ions, respectively.

128 2.6. HILIC (2-AB) Each mAb (200 $\mu \mathrm{g})$ was deglycosylated by incubation with $2 \mu \mathrm{g}$ PNGase $\mathrm{F}(500,000$ $129 \mathrm{U} / \mathrm{ml}$, New England Biolabs) at $37^{\circ} \mathrm{C}$ for $3 \mathrm{~h}$. Released glycans were labelled with $2-\mathrm{AB}$ at $65^{\circ} \mathrm{C}$ for $3 \mathrm{~h}$ 130 (Glyko Signal 2-AB Labeling Kit, ProZyme), and then purified using dedicated GlikoClean S Cartridges 131 (Prozyme). Labeled glycans were washed with 96\% acetonitrile (ACN), eluted from the cartridges and 132 evaporated to dryness using a speedvac, then reconstituted in 30:70 water/ACN (v/v). Analysis were 133 performed by HILIC using an Agilent AdvanceBio Glycan column ( 2.1 x $150 \mathrm{~mm}, 1.8 \mu \mathrm{m})$ on a Waters 
134 ACQUITY UPLC I-Class system equipped with a binary solvent delivery pump, an auto-sampler, a UV-

135 DAD and a fluorescence detector (FD) set at $\lambda_{\mathrm{ex}}=260 \mathrm{~nm}$ and $\lambda_{\mathrm{em}}=430 \mathrm{~nm}$. The system included a flow 136 through needle (FTN) injection system with a $15 \mu \mathrm{L}$ needle. Data acquisition, data handling and 137 instrument control were performed with Empower 2 (Waters, Milford, MA, USA). Mobile phase consisted of $20 \mathrm{mM}$ Ammonium Formate solution (A) and ACN (B). The column temperature was set to $55{ }^{\circ} \mathrm{C}$, and injection volume was $2 \mu \mathrm{L}$ corresponding to $0.08-0.2$ ug glycan sample. The flow rate was set to $0.5 \mathrm{~mL} / \mathrm{min}$, and the gradient conditions consisted of $80 \%$ to $60 \% \mathrm{~B}$ in 25 minutes, followed by a 3 min washing step at $20 \%$ B and a 15 min re-equilibration step. Peaks were manually integrated and relative glycan compositions were calculated. For the correct identification of the labelled glycans, UHPLC-MS analysis were also performed using an ACQUITY UPLC system (Waters), equipped with a binary pumping system and fixed loop injector of $5 \mu$ l. This UHPLC was coupled to a fluorescence detector (FD) and an electrospray time-of-flight mass spectrometer (Xevo ${ }^{\mathrm{TM}} \mathrm{Q}$-ToF, Waters). The mass spectrometer was operated in the positive ion mode and ions were scanned over an $\mathrm{m} / \mathrm{z}$ range of 500 2500 with a $1 \mathrm{~s}$ scan rate. Capillary voltage was set to $3.0 \mathrm{kV}$, sample cone voltage to $35 \mathrm{~V}$, source temperature to $120^{\circ} \mathrm{C}$, desolvation gas temperature to $350^{\circ} \mathrm{C}$ and gas flow to $800 \mathrm{~L} / \mathrm{h}$. The instrument was calibrated using the singly charged ions produced by a $2 \mu \mathrm{g} / \mu \mathrm{L}$ sodium iodide solution in 2propanol/water (1:1). Data acquisition and analysis were performed with MassLynx 4.1 (Waters). In all cases, a 2-AB labelled dextran ladder standard $(1 \mathrm{pmol} / \mu \mathrm{L})$ was also injected before and after a series of 5 samples, to check the repeatability of the injections and verify that no drift in retention times was observed.

\section{Results and discussions}

\subsection{Characterization of N-Glycopeptide by CE-ESI-MS.}

mAbs are glycosylated proteins whose $\mathrm{N}$-glycans are naturally incorporated in the protein during secretion into the extracellular environment. Extensive glycans characterization in terms of structure and relative abundance is of prime importance. The main goal of this study was to demonstrate the possibility to use CE-ESI-MS method for performing glycosylation profiling of a large panel of therapeutic mAbs. Therefore, we realized a systematic study of glycosylation characterization on ten different mAbs produced in CHO, NSO and SP2/0 cell lines (Table 1). To evaluate the viability of CE-ESIMS, we focused our characterization on the main Fc N-glycan species typically found in therapeutic IgG mAb produced in the above mentioned cell lines and listed in Table 1. In this section, natalizumab results have been selected as example to describe the CE-ESI-MS methodology allowing to assess the in-depth N-glycan characterization. Fig. 1a illustrates the separation obtained for the tryptic digest of 
electropherogram showed that all peptides migrated between 15 and $40 \mathrm{~min}$. As tandem MS data interpretation and peptide identification was automatically done using Mascot, to obtain fast and accurate data treatment, it was necessary to manually evaluate the CE-ESI-MS/MS data in order to identify the glyco-variants and determine their structures.
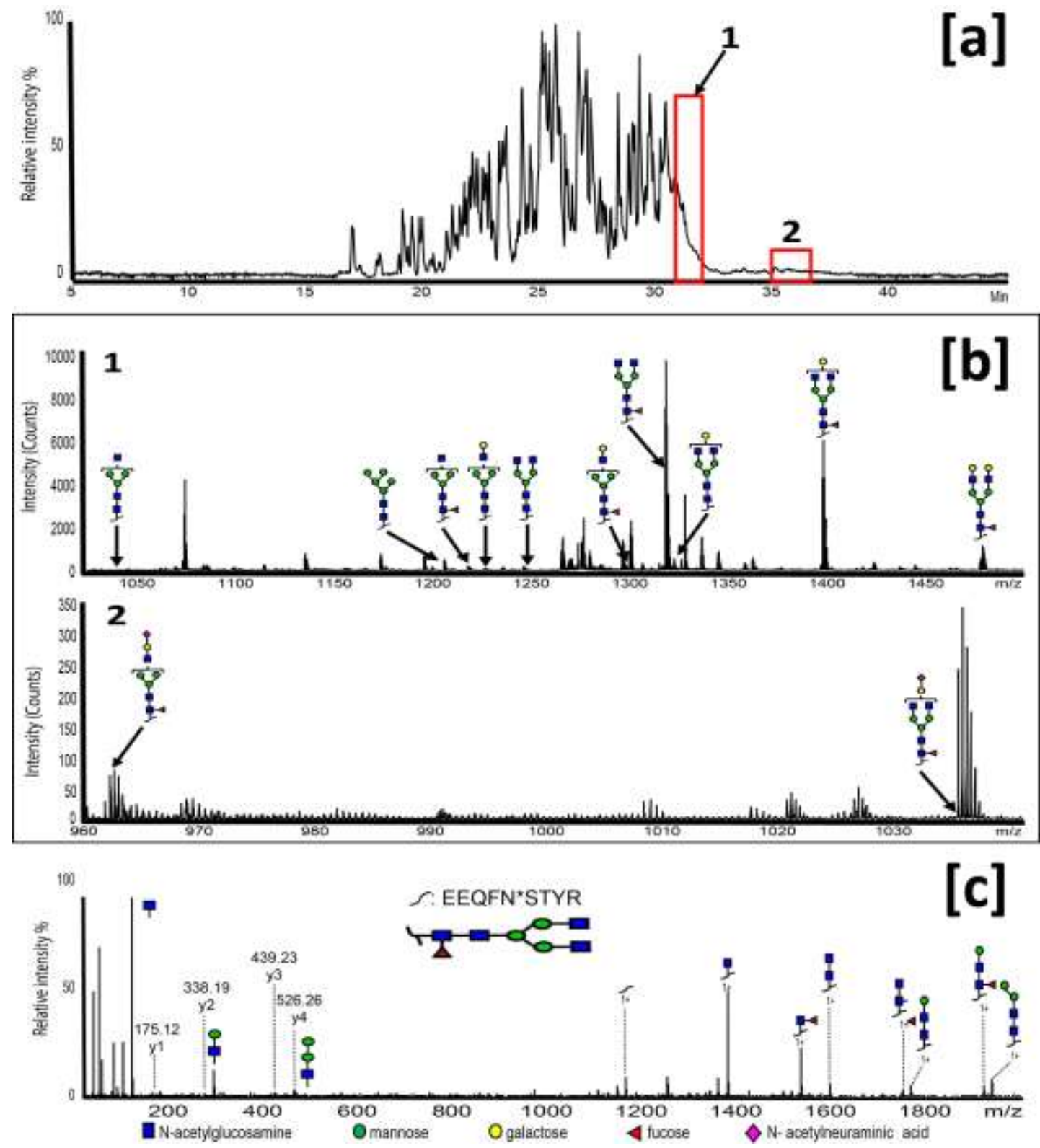

Fig. 1. (a) Base Peak Electropherogram corresponding to the analysis by CE-ESI-MS/MS of natalizumab tryptic digest. (b) MS spectrum of $30.5-31.9 \mathrm{~min}$ and $34.9-36.5$. (c) MS/MS fragmentation spectra of [EEQFNSTYR] + GOF. Experimental conditions described in Experimental section.

Peak assignment of glyco-structures was performed based on accurate mass measurement in MS1, provided by high resolution MS (mass accuracy below $2 \mathrm{ppm}$ ) (Fig. 1b) and collision induced decay (CID) fragmentation spectra (Fig. 1c), respectively. Indeed, MS/MS spectra exhibited the fragmentation of glycan moieties present on the glycopeptide, giving structural information on the glycans along with 
reinforcing the confidence of the identification. Furthermore, the obtained electropherogram showed

182 the separation of several glycopeptides, demonstrating the benefit of using CE for such 183 characterization. The charge-based CE separation allowed the baseline resolution of sialic acid and 184 neutral glycans located on the peptide EEQFN ${ }^{300}$ STYR. Fig. 1a represents two windows on the 185 electropherogram, corresponding to the neutral glycans separation (between 30.5 and $31.9 \mathrm{~min}$ ) and 186 to the sialic acid moieties separation (between 34.9 and $36.5 \mathrm{~min}$ ). Moreover, particular glycopeptides having a difference of only one galactose could also be baseline separated. Glycopeptides having such a small difference in mass tend to compete against each other during the ionization process, potentially interfering with relative quantification, thus the capacity to separate them is clearly an intriguing advantage. To perform the glycans profiling of each $\mathrm{mAb}$, relative occurrence levels were estimated

191 from the sum of isotopic peak intensities, considering all charge states of the ion corresponding to one 192 glycopeptide (Fig. 2a and Table S-1). A comparison of all glycoforms abundance was then realized (Fig.

193 2b). To validate the method reproducibility, the digestions of each mAb were performed three times 194 using different experimenters and triplicate injections of each digested sample were carried out. The 195 relative occurrence glycan levels reported in Table 1 were calculated for a selected $\mathrm{mAb}$ as the average 196 of all relative abundances of the nine values (three digestions and three injections per digested 197 samples), with a confidence interval of $95 \%$.
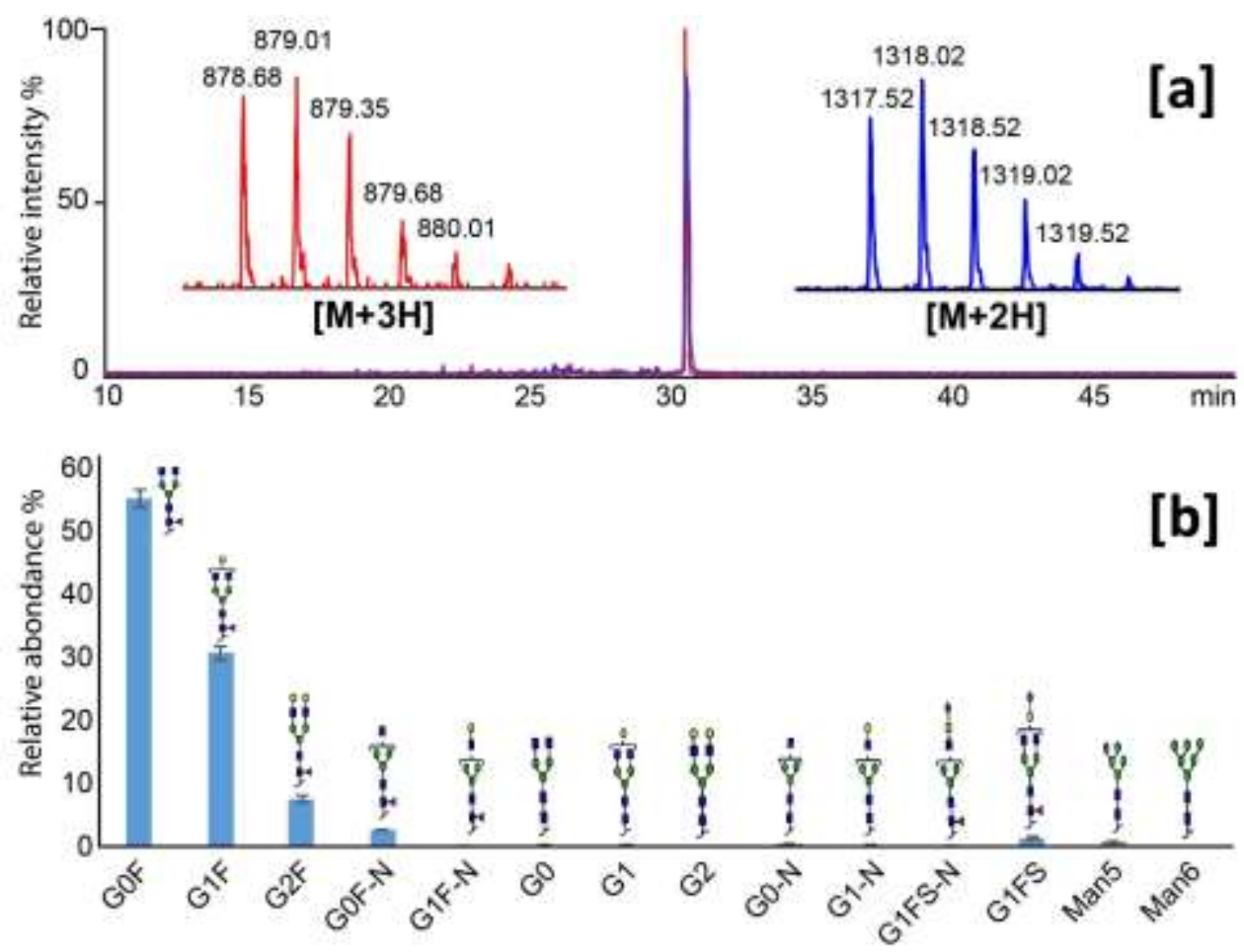

Fig. 2. (a) Extracted Ion Electropherogram (EIE) of $\mathrm{m} / \mathrm{z}$ ratios 878.68 and 1317.52 ([EEQFN*STYR] + GOF) and corresponding MS/MS fragmentation spectra (right-hand side). (b) Glycoforms relative abundance results obtained through the CE-ESI-MS data for the natalizumab Fc glycopeptide. 


\subsection{Evaluation of CE-ESI-MS method performance}

204 To assess the performance of the CE-ESI-MS methodology with respect to accuracy and precision, each mAb glycosylation profile was compared with the reference method, namely HILIC-FD glycosylation profile obtained upon release and 2-AB-labeling of the glycans. HILIC-FD acquisitions were performed in triplicate and peaks on the FD chromatogram were manually integrated for estimating the relative

208 glycan compositions. The deviations observed for retention times were minimal $\left(R \mathrm{RD}_{\mathrm{RT}}=0.39 \%\right.$, 209 calculated on GOF, for $n=30$ ). Peak assignment of the 2AB-glycans was accomplished by online coupling 210 of HILIC with ESI-MS. A detailed list of the glycan composition and the theoretical masses of the 211 unlabelled/labelled glycans is shown in Table 2. The theoretical 2AB-glycan masses were used to obtain 212 the extracted ion chromatogram (EIC) of each glycan. Furthermore, GlycoMod software 213 (http://web.expasy.org/glycomod/) was eventually used for the prediction of the possible glycan 214 structures based on the experimentally determined masses.
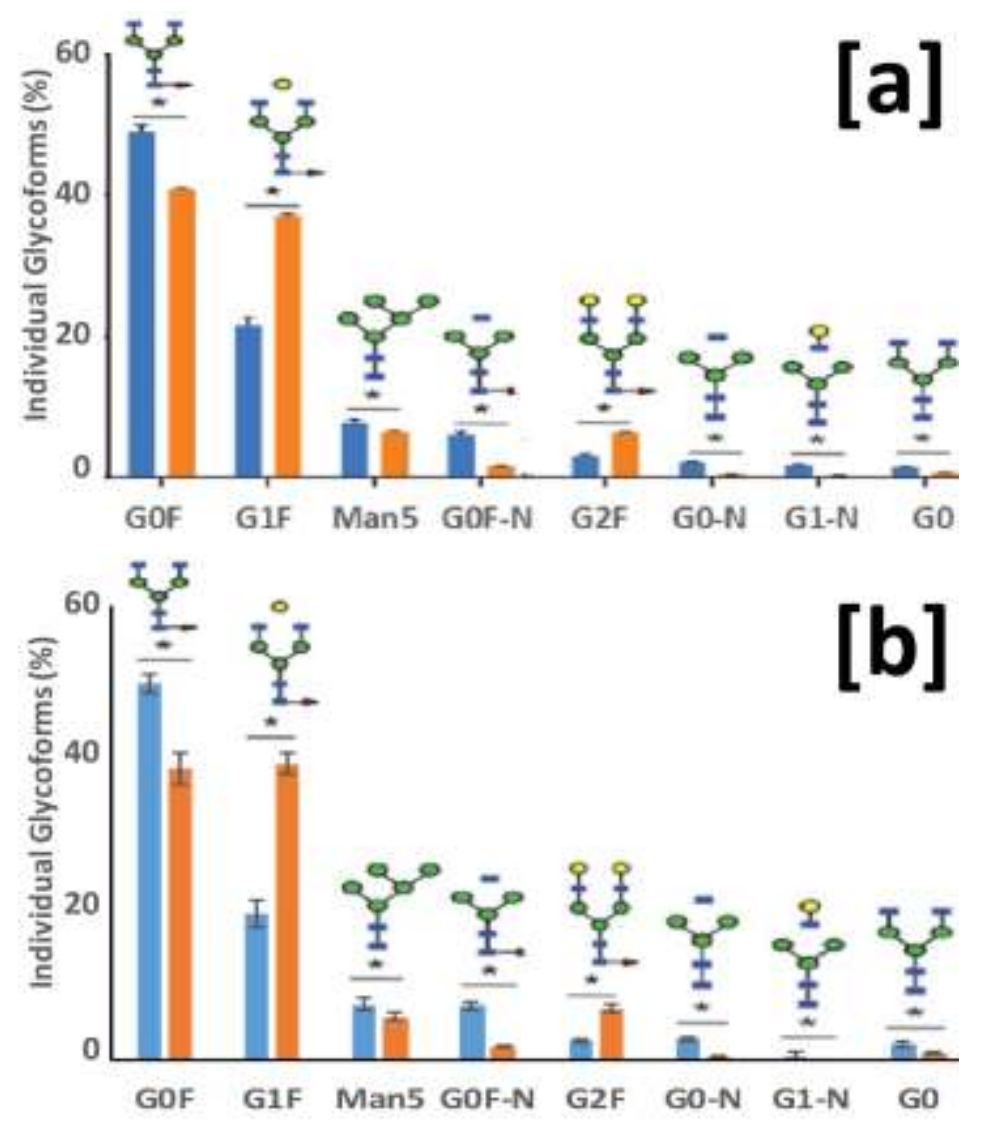
Remicade $\mathbf{R e m s i m a}$ Fig. 3. Comparison of Infliximab-Remicade ${ }^{\circledR}$ and infliximab-Remsima ${ }^{\circledR}$ glycoprofiling. (a) Quantification of $\mathrm{N}$ glycans adapted following the method of Pisupati et al (adapted with permission from [30]. Copyright (2017) American Chemical Society. (b) Quantification of N-glycans following CE-ESI-MS analysis. 
Table 1 compiles the results of CE-ESI-MS and HILIC-FD (2-AB) relative abundance values obtained for 221 each mAb. As described in the literature [20], HILIC-FD shows excellent precision with low standard 222 deviations (with the exception of Infliximab-Remsima ${ }^{\circledR}$ analysis). The suggested CE-ESI-MS method also 223 presents low absolute variation with values below $4 \%$ for the different glycan structures. These values 224 are comparable to those determined for other MS-based methods, such as NanoLC-ESI-MS described elsewhere [21]. It is worth noticing that for each mAb, the deviations were obtained based on the combination of digestions and injections performed in triplicates by different experimenters over an extended period of several weeks, thus the results strongly support the performance of the method in terms of robustness and reproducibility. Moreover, the relative occurrence level estimated by CE-ESIMS method were in good agreement for the values obtained with the reference HILIC-FD method. For GOF and G1F, which represent at least $75 \%$ of the total glycosylation of each mAb, the relative absolute difference between CE-ESI-MS means and HILIC-FD means expressed as a percentage $\left(100 * \mid\right.$ Mean $_{\mathrm{CE}^{-}}$

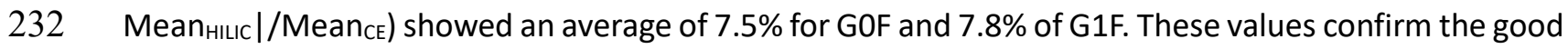
233 fit between the two methodologies for the major forms of glycosylation. Moreover, for glycosylation 234 expressed at least at $10 \%$ of the total glycoforms (i.e. G2F of Palivizumab), this value is up to $20 \%$ meaning a good variability between CE-ESI-MS and HILIC (2-AB) mean amount. For glycosylation representing less than $10 \%$ of the total glycoforms, the relative absolute differences between HILIC-FD and CE-ESI-MS are no longer representative, because these values can be very high, due to low degree of expression.

239 The relative quantification of mono-antennary structures, defined by the lack of $\mathrm{N}$-acetylglucosamine (GOF-N, G1F-N, G0-N, G1-N), is known to be problematic using MS-based methods. Indeed, in-source fragmentation of bi-antennary structures resulting in the loss of one antenna can generate elevated mono-antennary structures levels, along with a charge reduction that is commonly observed in MS spectra and that is a consequence of a loss of the $\mathrm{N}$-acetylglucosamine [21]. While only low or similar

244 levels of mono-antennary structures were detected in CE-ESI-MS for eight mAbs, higher levels of these 245 glycovariants were detected for natalizumab and nivolumab, as compared to HILIC-FD (Table S-2). 246 However, for these two mAbs, differences between the mono-antennary means obtained by CE-ESI247 MS and HILIC-FD were not aberrant, and no charge state reduction was observed by CE-ESI-MS, 248 meaning that the detected sum of mono-antennary structures were not over-estimated. Moreover, 249 this result confirmed that during ESI-MS analysis of glycopeptides, in source decay can efficiently be 250 avoided through the proper choice of the MS conditions and voltages, even for CE-ESI-MS method [21].

251 The sum of afucosylated species $(G 0, G 1, G 2)$ is a relevant parameter for antibody effector function. 252 For nine mAbs, similar levels of $\mathrm{G} 0+\mathrm{G} 1+\mathrm{G} 2$ were observed. Only trastuzumab showed a difference 253 between CE-ESI-MS (8.3\%) and HILIC-FD (4.4\%) (Table S-2). Similarly, the sum of highly mannosylated 
species (M5, M6) was evaluated and similar levels of M5+M6 were observed for seven mAbs, along

255 with small differences concerning M5 species for adalimumab, infliximab-Remicade ${ }^{\circledR}$ and palivizumab.

256 Finally, good correlations were observed for the mean levels of sialylated structures sum (G1FS, G1FS-

257 N). Overall comparisons of results obtained by CE-ESI-MS approach and HILIC-FD reference method 258 showed very similar glycoprofiling of the ten therapeutic mAbs. CE-ESI-MS demonstrated to be a 259 valuable method to characterize and quantify with high accuracy, precision and robustness the most largely expressed glycan species as well as the low abundance glycoforms.

261 Recently, Pisupati et al. published an important work describing a multidimensional analytical comparison of infliximab-Remicade ${ }^{\circledR}$ and the biosimilar infliximab-Remsima ${ }^{\circledR}$ [30]. They performed the glycoforms quantification by LC-MS using trypsin-digested products and demonstrated, for the first time, significant differences in the N-Glycan distributions for infliximab-Remicade ${ }^{\circledR}$ and infliximabRemsima $^{\circledR}$ (Fig. 3a). To confirm the assessment of CE-ESI-MS method in performing the relative quantitation of mAbs glycopeptides, we compared our infliximab-Remicade ${ }^{\circledR}$ and infliximab-Remsima means with those obtained by Pisupati et al. It must be highlighted that no collaboration was carried out between Prof. Schwendeman's group and our laboratory, which means that samples were not from the same batch, and that experimenters and instrumentations were different. Fig. $3 b$ represents the glycoprofiling of infliximab-Remicade ${ }^{\circledR}$ and infliximab-Remsima following CE-ESI-MS analysis for the selected $\mathrm{N}$-glycan species. Comparison between Pisupati et al. results and our profiles highlights a total similarity between the two glycoprofilings. While the confirmation of CE-ESI-MS performance in term of N-Glycan species quantification was proved, significant differences in the N-Glycan distributions for infliximab-Remicade ${ }^{\circledR}$ and infliximab-Remsima ${ }^{\circledR}$ were confirmed.

Infliximab-Inflectra ${ }^{\circledR}$ is another biosimilar that was studied in this work and not reported by Pisupati et al.. Thanks to the CE-ESI-MS methodology, we showed for the first time significant differences in the N-Glycan distributions also for infliximab-Remicade ${ }^{\circledR}$ and infliximab-Inflectra ${ }^{\circledR}$ (Table 1).

\section{Conclusions}

282 To summarize, we reported here the development of a CE-ESI-MS methodology to perform relative 283 quantitation of $\mathrm{N}$-glycan species for $\mathrm{mAbs}$ characterization at the glycopeptides level. Validation in 284 terms of robustness and reproducibility of CE-ESI-MS method were demonstrated through the relative 285 quantitation of glycosylation profiles for ten different mAbs produced in different cell lines. A 
286 systematic comparison of the glycosylation patterns obtained for each mAbs was compared with that 287 obtained with the HILIC-FD reference method. Results obtained with the CE-ESI-MS approach and 288 HILIC-FD showed very similar glycoprofiling, demonstrating the attractiveness of CE-ESI-MS method to 289 characterize and quantify the glycosylation heterogeneity of a wide range of therapeutic mAbs, with 290 high accuracy and precision. Moreover, it must be mentioned that our CE-ESI-MS methodology is not restricted to the sole purpose of glycopeptides characterization and quantitation, but it can also be employed for the overall characterization of mAbs, including primary structure assessment with complete sequence coverage as well as identification and quantification of a large number of PTMs, all performed within a unique single analysis [27]. In our opinion, this work proves that CE-ESI-MS could 295 be a viable alternative to LC-ESI-MS for glycosylation profiling and should be considered as an 296 innovative approaches in MS-based proteomics applied to mAbs characterization.

\section{Acknowledgments}

299 Emmanuelle Leize-Wagner would like to thank Sciex for the fruitful collaboration and the support. The 300 authors would like to express their gratitude to Camille Banholzer, Jordan Kirmann and Charly Renard 301 (LSMIS, Université de Strasbourg, France), P. Hammann, Lauriane Kuhn and J. Chicher (Institut de 302 Biologie Moléculaire et Cellulaire, Strasbourg, France) and MC. Janin-Bussat (Centre d'Immunologie 303 Pierre Fabre, St Julien en Genevois, France). This work was supported by the CNRS (UMR 7140), the 304 University of Strasbourg. Davy Guillarme also wishes to thank the Swiss National Science Foundation 305 for its financial support (31003A_159494). 
[1] A. Beck, T. Wurch, C. Bailly, N. Corvaia, Strategies and challenges for the next generation of therapeutic antibodies, Nat. Rev. Immunol. 10 (2010) 345-352.

311 [2] J.M. Reichert, Marketed therapeutic antibodies compendium, mAbs 4 (2012) 413-415.

312 [3] A. Beck, H. Diemer, D. Ayoub, F. Debaene, E. Wagner-Rousset, C. Carapito, A. Van Dorsselaer, S. Sanglier-Cianferani, 313 Analytical characterization of biosimilar antibodies and Fc-fusion proteins, Trac-Trends Anal. Chem. 48 (2013) 81-95.

314 [4] W. Wang, S. Singh, D.L. Zeng, K. King, S. Nema, Antibody structure, instability, and formulation, J. Pharm. Sci. 96 (2007) 315 1-26.

316 [5] A. Beck, E. Wagner-Rousset, MC. Bussat, M. Lokteff, C. Klinguer-Hamour, JF. Haeuw, L. Goetshc, T. Wurch, A. Van

317 Dorsselaer, N. Corvaïa Trends in glycosylation, glycoanalysis and glycoengineering of therapeutic antibodies and Fc-fusion 318 proteins, Curr. Pharm. Biotechnol. 9 (2008) 482-501.

319 [6] A. Beck, T. Wurch, N. Corvaïa Therapeutic antibodies and derivatives: from the bench to the clinic. Curr. Pharm. 320 Biotechnol. 9 (2008) 421-422.

321 [7] R. Jefferis Glycosylation as a strategy to improve antibody-based therapeutics Nat. Rev. Drug. Discov. 8 (2009) $226-234$.

322 [8] DS. Dimitrov, JD. Marks Therapeutic antibodies: current state and future trends-is a paradigm change coming soon? 323 Methods Mol. Biol. 525 (2009) 1-27.

324 [9] D. Ayoub, W. Jabs, A. Resemann, W. Evers, C. Evans, L. Main, C. Baessmann, E.Wagner-Rousset, D. Suckau, A. Beck, Correct primary structure assessment and extensive glyco-profiling of cetuximab by a combination of intact,middle-up, middle-down and bottom-up ESI and MALDI mass spectrometry techniques, mAbs 5 (2013) 699-710.

[10] R. Gahoual, A. Burr, J.M. Busnel, L. Kuhn, P. Hammann, A. Beck, Y.N. Francois, E. Leize-Wagner, Rapid and multi-level characterization of trastuzumab using sheathless capillary electrophoresis-tandem mass spectrometry, mAbs 5 (2013) 479490.

330 [11] D. Reusch, M.L. Tejada, Fc glycans of therapeutic antibodies as critical quality attributes, Glycobiology 25 (2015) 1325$331 \quad 1334$

332 [12] M. Schiestl, T. Stangler, C. Torella, T. Cepeljnik, H. Toll, R. Grau, Acceptable changes in quality attributes of glycosylated 333 biopharmaceuticals, Nat. Biotechnol. 29 (2011) 310-312.

334 [13] E. Largy, F. Cantais, G. Van Vyncht, A. Beck, A. Delobel Orthogonal liquid chromatography-mass spectrometry methods for the comprehensive characterization of therapeutic glycoproteins, form released glycans to intact protein level J.

336 Chromatogr. A 1498 (2017) 128-146.

[14] R. Niwa, A. Natsume, A. Uehara, M. Wakitani, S. lida, K. Uchida, M. Satoh, K.Shitara, IgG subclass-independent improvement of antibody-dependentcellular cytotoxicity by fucose removal from Asn297-linkedoligosaccharides, J. Immunol. Methods 306 (2005) 151-160

340 [15] S.A. Brooks, Appropriate glycosylation of recombinant proteins for human use: implications of choice of expression 341 system, Mol. Biotechnol. 28 (2004)241-256.

342 [16] R.G. Spiro, Protein glycosylation: nature, distribution, enzymatic formation, and disease implications of glycopeptide 343 bonds, Glycobiology 12 (2002)43R-56R.

344 [17] V. Dotz, R. Haselberg, A. Shubhakar, R.P. Kozak, D. Falck, Y. Rombouts, D. Reusch, G.W. Somsen, D.L. Fernandes, M. Wuhrer, Mass spectrometry for glycosylation analysis of biopharmaceuticals, TrAC Trends Anal. Chem. 73(2015) 1-9.

346 [18] L. Zhang, S. Luo, B. Zhang, Glycan analysis of therapeutic glycoproteins, mAbs 8 (2016) 205-215. 
[20] D. Reusch, M. Haberger, B. Maier, M. Maier, R. Kloseck, B. Zimmermann, M.Hook, Z. Szabo, S. Tep, J. Wegstein, N. Alt, P. Bulau, M. Wuhrer, Comparison of methods for the analysis of therapeutic immunoglobulin G Fc-glycosylation profilespart 1: separation-based methods, mAbs 7 (2015)167-179.

[21] D. Reusch, M. Haberger, D. Falck, B. Peter, B. Maier, J. Gassner, M. Hook, K. Wagner, L. Bonnington, P. Bulau, M. Wuhrer, Comparison of methods for the analysis of therapeutic immunoglobulin G Fc-glycosylation profiles-Part 2:Mass spectrometric methods, mAbs 7 (2015) 732-742.

356 [22] A.Beck, S. Sanglier-Cianferani, A. Van Dorsselaer Biosimilar, biobetter, and next generation antibody characterization by mass spectrometry, Anal Chem 84 (2012) 4637-4646.

358 [23] S. Thobhani, CT. Yuen, MJ. Bailey, C .Jones Identification and quantification of N-linked oligosaccharides released from glycoproteins: an inter-laboratory study, Glycobiology 19 (2009) 201-211.

360 [24] M. Wuhrer. Glycomics using mass spectrometry. Glycoconj. J. 30 (2013) 11-22.

361 [25] A. Banazadeh, L. Veillon, KM. Wooding, M. Zabet-Moghaddam, Y. Mechref Electrophresis, 38 (2017) 162-189.

362 [26] L.A. Gennaro, O. Salas-Solano, On-line CE-LIF-MS technology for the direct characterization of N-linked glycans from therapeutic antibodies. Anal. Chem. 80 (2008) 3838-3845.

364 [27] R. Gahoual, J.-M. Busnel, A. Beck, Y.-N. François, E. Leize-Wagner, Full Antibody Primary Structure and Microvariant Characterization in a Single Injection Using Transient Isotachophoresis and Sheathless Capillary Electrophoresis-Tandem Mass Spectrometry, Anal. Chem. 86 (2014) 9074-9081.

[28] R. Gahoual, M. Biacchi, J. Chicher, L. Kuhn, P. Hammann, A. Beck, E.Leize-Wagner, Y.N. Francois, Monoclonal antibodies biosimilarity assessment using transient isotachophoresis capillary zone electrophoresis-tandem mass spectrometry, mAbs 6 (2014) 1464-1473.

[29] A.A.M. Heemskerk, M. Whurer, J.M. Busnel, C.A.M. Koeleman, M.H.J. Selman, G. Vidarsson, R. Kapur, B. Shoenmaker, R.J.E. Derks, A.M. Deelder, O.A. Mayboroda, Coupling porous sheathless interface MS with transient-ITP in neutral capillaries for improved sensitivity in glycopeptide analysis. Electrophoresis 34 (2013) 383-387.

[30] K. Pisupati, Y. Tian, S. Okbazghi, A. Benet, R. Ackermann, M. Ford, S. Saveliev, CM. Hosfield, M. Urh, E. Carlson, C. 


\begin{tabular}{|c|c|c|c|c|c|c|c|c|c|c|c|}
\hline \multirow[b]{3}{*}{$\begin{array}{l}\text { Glycan } \\
\text { Species }\end{array}$} & \multirow[b]{3}{*}{$\begin{array}{l}\text { Structural } \\
\text { Scheme }\end{array}$} & \multirow{2}{*}{\multicolumn{2}{|c|}{$\begin{array}{c}\text { Adalimumab } \\
\left.\text { (Humira }^{\circledR}\right)\end{array}$}} & \multirow{2}{*}{\multicolumn{2}{|c|}{$\begin{array}{c}\text { Infliximab } \\
\left(\text { Remicade }^{\circledR}\right) \\
\end{array}$}} & \multirow{2}{*}{\multicolumn{2}{|c|}{$\begin{array}{c}\text { Infliximab } \\
\left(\text { Inflectra }{ }^{\circledR}\right)\end{array}$}} & \multirow{2}{*}{\multicolumn{2}{|c|}{$\begin{array}{c}\text { Infliximab } \\
\left(\text { Remsima }^{\circledR}\right)\end{array}$}} & \multirow{2}{*}{\multicolumn{2}{|c|}{$\begin{array}{l}\text { Trastuzumab } \\
\left(\text { Herceptin }^{\circledR}\right)\end{array}$}} \\
\hline & & & & & & & & & & & \\
\hline & & $\begin{array}{c}\text { HILIC } \\
\text { (2-AB) }\end{array}$ & $\begin{array}{l}\text { CE with } \\
\text { Q-TOF }\end{array}$ & $\begin{array}{c}\text { HILIC } \\
(2-A B)\end{array}$ & $\begin{array}{l}\text { CE with } \\
\text { Q-TOF }\end{array}$ & $\begin{array}{c}\text { HILIC } \\
(2-A B)\end{array}$ & $\begin{array}{l}\text { CE with } \\
\text { Q-TOF }\end{array}$ & $\begin{array}{c}\text { HILIC } \\
(2-A B)\end{array}$ & $\begin{array}{l}\text { CE with } \\
\text { Q-TOF }\end{array}$ & $\begin{array}{l}\text { HILIC } \\
(2-A B)\end{array}$ & $\begin{array}{l}\text { CE with } \\
\text { Q-TOF }\end{array}$ \\
\hline $\begin{array}{l}\text { G0F } \\
\text { [H3N4F1] }\end{array}$ & & $\begin{array}{l}69.3 \\
(0.1)\end{array}$ & $\begin{array}{l}65.7 \\
(2.4)\end{array}$ & $\begin{array}{l}\mathbf{5 3 . 7} \\
(0.1)\end{array}$ & $\begin{array}{l}49.7 \\
(1.3)\end{array}$ & $\begin{array}{l}41.6 \\
(0.1)\end{array}$ & $\begin{array}{l}39.3 \\
(4.0)\end{array}$ & $\begin{array}{l}44.6 \\
(5.1)\end{array}$ & $\begin{array}{l}38.6 \\
(2.0)\end{array}$ & $\begin{array}{l}48.7 \\
(0.4)\end{array}$ & $\begin{array}{l}41.6 \\
(1.1)\end{array}$ \\
\hline G1F & & 17.9 & 18.0 & 21.4 & 19.3 & 40.2 & 39.7 & 37.5 & 39.2 & 35.4 & 38.7 \\
\hline [H4N4F1] & & $(<0.1)$ & (3.0) & $(0.1)$ & (1.8) & $(<0.1)$ & (2.2) & (3.7) & (1.4) & $(0.2)$ & $(0.8)$ \\
\hline $\begin{array}{l}\text { G2F } \\
{[\mathrm{H} 5 \mathrm{~N} 4 \mathrm{~F} 1]}\end{array}$ & & $\begin{array}{c}1.3 \\
(<0.1)\end{array}$ & $\begin{array}{c}\mathbf{0 . 8} \\
(0.8)\end{array}$ & $\begin{array}{c}2.1 \\
(<0.1)\end{array}$ & $\begin{array}{l}2.5 \\
(03)\end{array}$ & $\begin{array}{c}\mathbf{5 . 7} \\
(<0.1)\end{array}$ & $\begin{array}{c}6.4 \\
(1.9)\end{array}$ & $\begin{array}{c}4.7 \\
(1.7)\end{array}$ & $\begin{array}{c}6.8 \\
(0.6)\end{array}$ & $\begin{array}{c}5.3 \\
(<0,1)\end{array}$ & $\begin{array}{c}7.2 \\
(0.6)\end{array}$ \\
\hline GOF-N & & 2.5 & 3.7 & 6.3 & 7.3 & 1.4 & 1.7 & 1.7 & 1.8 & 1.5 & 1.3 \\
\hline [H3N3F1] & & $(<0.1)$ & (1.0) & $(<0.1)$ & $(0.5)$ & $(<0.1)$ & $(0.4)$ & $(0.6)$ & $(0.2)$ & $(<0.1)$ & (0.1) \\
\hline $\begin{array}{l}\text { G1F-N } \\
{[\text { H4N3F1] }}\end{array}$ & & $\begin{array}{c}1.4 \\
(<0.1)\end{array}$ & $\begin{array}{c}\mathbf{0 . 1} \\
(0.4)\end{array}$ & $\begin{array}{c}2.5 \\
(<0.1)\end{array}$ & $\begin{array}{c}3.2 \\
(0.4)\end{array}$ & $\begin{array}{c}0.8 \\
(<0.1)\end{array}$ & $\begin{array}{c}0.8 \\
(0.7)\end{array}$ & $\begin{array}{c}0.8 \\
(<0.1)\end{array}$ & $\begin{array}{c}\mathbf{0 . 6} \\
(0.4)\end{array}$ & $\begin{array}{c}1.7 \\
(<0.1)\end{array}$ & $\begin{array}{c}0.5 \\
(0.4)\end{array}$ \\
\hline $\begin{array}{l}\text { G0 } \\
\text { [H3N4] }\end{array}$ & & $\begin{array}{c}0.8 \\
(<0.1)\end{array}$ & $\begin{array}{c}0.5 \\
(0.8)\end{array}$ & $\begin{array}{c}1.3 \\
(<0.1)\end{array}$ & $\begin{array}{c}2.1 \\
(0.3)\end{array}$ & $\begin{array}{c}0.6 \\
(<0.1)\end{array}$ & $\begin{array}{c}0.8 \\
(0.1)\end{array}$ & $\begin{array}{c}0.8 \\
(0.3)\end{array}$ & $\begin{array}{c}1.0 \\
(0.1)\end{array}$ & $\begin{array}{c}3.5 \\
(<0.1)\end{array}$ & $\begin{array}{c}5.3 \\
(0.3)\end{array}$ \\
\hline $\begin{array}{l}\text { G1 } \\
\text { [H4N4] }\end{array}$ & & n.d. & $\begin{array}{c}0.5 \\
(1.3)\end{array}$ & $\begin{array}{c}0.1 \\
(<0.1)\end{array}$ & $\begin{array}{c}0.1 \\
(0.3)\end{array}$ & $\begin{array}{c}0.1 \\
(<0.1)\end{array}$ & n.d. & $\begin{array}{c}0.1 \\
(<0.1)\end{array}$ & $\begin{array}{c}0.1 \\
(0.3)\end{array}$ & $\begin{array}{c}0.5 \\
(<0.1)\end{array}$ & $\begin{array}{c}2.9 \\
(0.1)\end{array}$ \\
\hline $\begin{array}{l}\text { G2 } \\
\text { [H5N4] }\end{array}$ & & n.d. & n.d. & $\begin{array}{c}0.3 \\
(<0.1)\end{array}$ & n.d. & $\begin{array}{c}0.1 \\
(<0.1)\end{array}$ & n.d. & $\begin{array}{c}0.1 \\
(<0.1)\end{array}$ & $\begin{array}{c}0.1 \\
(0.1)\end{array}$ & $\begin{array}{c}0.4 \\
(<0.1)\end{array}$ & $\begin{array}{c}0.1 \\
(<0.1)\end{array}$ \\
\hline $\begin{array}{l}\text { GO-N } \\
{[\mathrm{H} 3 \mathrm{~N} 3]}\end{array}$ & & $\begin{array}{c}0.4 \\
(<0.1)\end{array}$ & n.d. & $\begin{array}{c}1.8 \\
(<0.1)\end{array}$ & $\begin{array}{c}2.8 \\
(0.3)\end{array}$ & $\begin{array}{c}0.5 \\
(<0.1)\end{array}$ & $\begin{array}{c}\mathbf{0 . 6} \\
(0.1)\end{array}$ & $\begin{array}{c}0.6 \\
(0.3)\end{array}$ & $\begin{array}{c}0.6 \\
(0.1)\end{array}$ & $\begin{array}{c}0.8 \\
(<0.1)\end{array}$ & $\begin{array}{c}0.7 \\
(0.1)\end{array}$ \\
\hline $\begin{array}{l}\text { G1-N } \\
{[\mathrm{H} 4 \mathrm{~N} 3]}\end{array}$ & & n.d. & n.d. & $\begin{array}{c}0.7 \\
(<0.1)\end{array}$ & $\begin{array}{c}0.6 \\
(0.6)\end{array}$ & $\begin{array}{c}0.1 \\
(<0.1)\end{array}$ & $\begin{array}{c}0.1 \\
(0.1)\end{array}$ & $\begin{array}{c}0.1 \\
(<0.1)\end{array}$ & $\begin{array}{c}0.1 \\
(0.1)\end{array}$ & n.d. & $\begin{array}{c}0.1 \\
(0.1)\end{array}$ \\
\hline $\begin{array}{l}\text { G1FS-N } \\
\text { [H4N3FS1] }\end{array}$ & & n.d. & n.d. & $\begin{array}{c}2.8 \\
(<0.1)\end{array}$ & $\begin{array}{c}3.4 \\
(1.0)\end{array}$ & $\begin{array}{c}1.2 \\
(0.1)\end{array}$ & $\begin{array}{l}1.3 \\
(0.4)\end{array}$ & $\begin{array}{c}1.0 \\
(0.3)\end{array}$ & $\begin{array}{c}1.4 \\
(0.3)\end{array}$ & n.d. & n.d. \\
\hline $\begin{array}{l}\text { G1FS } \\
\text { [H4N4FS1] }\end{array}$ & & n.d. & n.d. & $\begin{array}{c}1.5 \\
(<0.1)\end{array}$ & $\begin{array}{c}1.6 \\
(0.5)\end{array}$ & $\begin{array}{c}3.0 \\
(<0.1)\end{array}$ & $\begin{array}{c}3.9 \\
(1.2)\end{array}$ & $\begin{array}{c}2.3 \\
(0.4)\end{array}$ & $\begin{array}{c}3.9 \\
(0.8)\end{array}$ & n.d. & n.d. \\
\hline $\begin{array}{l}\text { M5 } \\
\text { [H5N2] }\end{array}$ & & $\begin{array}{c}4.65 \\
(<0.1)\end{array}$ & $\begin{array}{c}8.2 \\
(2.6)\end{array}$ & $\begin{array}{c}5.4 \\
(<0.1)\end{array}$ & $\begin{array}{c}7.4 \\
(0.9)\end{array}$ & $\begin{array}{c}4.6 \\
(<0.1)\end{array}$ & $\begin{array}{c}5.5 \\
(0.3)\end{array}$ & $\begin{array}{c}5.3 \\
(1.4)\end{array}$ & $\begin{array}{c}5.8 \\
(0.6)\end{array}$ & $\begin{array}{c}1.8 \\
(<0.1)\end{array}$ & $\begin{array}{c}1.6 \\
(0.1)\end{array}$ \\
\hline $\begin{array}{l}\text { M6 } \\
{[\mathrm{H} 6 \mathrm{~N} 2]}\end{array}$ & & $\begin{array}{l}1.57 \\
(<0.1)\end{array}$ & $\begin{array}{l}2.57 \\
(0.9)\end{array}$ & $\begin{array}{c}0.1 \\
(<0.1)\end{array}$ & n.d. & $\begin{array}{c}0.3 \\
(<0.1)\end{array}$ & n.d. & $\begin{array}{c}0.3 \\
(<0.1)\end{array}$ & $\begin{array}{c}0.1 \\
(0.3)\end{array}$ & $\begin{array}{c}\mathbf{0 . 4} \\
(<0.1)\end{array}$ & n.d. \\
\hline
\end{tabular}




\begin{tabular}{|c|c|c|c|c|c|c|c|c|c|c|c|}
\hline \multirow[b]{2}{*}{$\begin{array}{l}\text { Glycan } \\
\text { Species }\end{array}$} & \multirow[b]{2}{*}{$\begin{array}{l}\text { Structural } \\
\text { Scheme }\end{array}$} & \multicolumn{2}{|c|}{$\begin{array}{c}\text { Palivizumab } \\
\left.\text { (Synagis }^{\circledR}\right)\end{array}$} & \multicolumn{2}{|c|}{$\begin{array}{c}\text { Natalizumab } \\
\left(\text { Tysabri }^{\circledR}\right)\end{array}$} & \multicolumn{2}{|c|}{$\begin{array}{c}\text { Nivolumab } \\
\text { (Opdivo }^{\circledR} \text { ) }\end{array}$} & \multicolumn{2}{|c|}{$\begin{array}{l}\text { Rituximab } \\
\left(\text { Rituxan }^{\circledR}\right)\end{array}$} & \multicolumn{2}{|c|}{$\begin{array}{c}\text { Panitumumab } \\
\left.\text { (Vectibix }^{\circledR}\right)\end{array}$} \\
\hline & & $\begin{array}{c}\text { HILIC } \\
(2- \\
\text { AB) }\end{array}$ & $\begin{array}{l}\text { CE with } \\
\text { Q-TOF }\end{array}$ & $\begin{array}{c}\text { HILIC } \\
(2- \\
\text { AB) }\end{array}$ & $\begin{array}{l}\text { CE with } \\
\text { Q-TOF }\end{array}$ & $\begin{array}{c}\text { HILIC } \\
(2-A B)\end{array}$ & $\begin{array}{l}\text { CE with } \\
\text { Q-TOF }\end{array}$ & $\begin{array}{c}\text { HILIC } \\
\text { (2-AB) }\end{array}$ & $\begin{array}{l}\text { CE with } \\
\text { Q-TOF }\end{array}$ & $\begin{array}{c}\text { HILIC } \\
(2-A B)\end{array}$ & $\begin{array}{l}\text { CE with } \\
\text { Q-TOF }\end{array}$ \\
\hline $\begin{array}{l}\text { G0F } \\
{[\mathrm{H} 3 \mathrm{~N} 4 \mathrm{~F} 1]}\end{array}$ & & $\begin{array}{l}29.4 \\
(2.9)\end{array}$ & $\begin{array}{l}29.2 \\
(0.5)\end{array}$ & $\begin{array}{l}\mathbf{5 9 . 1} \\
(0.3)\end{array}$ & $\begin{array}{l}\mathbf{5 5 . 1} \\
(1.3)\end{array}$ & $\begin{array}{l}69.8 \\
(0.4)\end{array}$ & $\begin{array}{l}60.5 \\
(2.1)\end{array}$ & $\begin{array}{l}44.5 \\
(0.1)\end{array}$ & $\begin{array}{l}\mathbf{4 0 . 6} \\
(1.8)\end{array}$ & $\begin{array}{l}41.6 \\
(0.2)\end{array}$ & $\begin{array}{l}40.6 \\
(2.1)\end{array}$ \\
\hline G1F & & 44.9 & 43.5 & 30.5 & 30.7 & 23.7 & 28.6 & 42.0 & 44.3 & 39.2 & 36.3 \\
\hline $\begin{array}{l}\text { [H4N4F1] } \\
\text { G2F }\end{array}$ & & $\begin{array}{l}(1.5) \\
13.7\end{array}$ & $\begin{array}{l}(2.0) \\
15.7\end{array}$ & $\begin{array}{c}(0.1) \\
4.7\end{array}$ & $\begin{array}{l}(1.1) \\
7.6\end{array}$ & $\begin{array}{l}(0.2) \\
2.7\end{array}$ & $\begin{array}{c}(1.0) \\
5.1\end{array}$ & $\begin{array}{c}(0.1) \\
7.3\end{array}$ & $\begin{array}{l}(1.1) \\
10.3\end{array}$ & $\begin{array}{l}(0.2) \\
7.4\end{array}$ & $\begin{array}{c}\text { (2.1) } \\
7.6\end{array}$ \\
\hline [H5N4F1] & & $(2.5)$ & (1.1) & $\begin{array}{l}4.7 \\
(0.1)\end{array}$ & $(0.6)$ & $(<0.1)$ & $\begin{array}{l}J .1 \\
(0.5)\end{array}$ & $(0.2)$ & $\begin{array}{l}10.5 \\
(0.9)\end{array}$ & $\begin{array}{l}10.4 \\
(0.4)\end{array}$ & (0.6) \\
\hline $\begin{array}{l}\text { GOF-N } \\
\text { [H3N3F1] }\end{array}$ & & $\begin{array}{c}2.4 \\
(0.5)\end{array}$ & $\begin{array}{c}2.4 \\
(0.2)\end{array}$ & $\begin{array}{c}1.1 \\
(<0.1)\end{array}$ & $\begin{array}{c}2.6 \\
(0.1)\end{array}$ & $\begin{array}{c}0.5 \\
(<0.1)\end{array}$ & $\begin{array}{c}3.1 \\
(0.2)\end{array}$ & $\begin{array}{c}0.9 \\
(<0.1)\end{array}$ & $\begin{array}{c}0.7 \\
(0.4)\end{array}$ & $\begin{array}{c}1.5 \\
(<0.1)\end{array}$ & $\begin{array}{c}1.9 \\
(0.3)\end{array}$ \\
\hline $\begin{array}{l}\text { G1F-N } \\
\text { [H4N3F1] }\end{array}$ & & $\begin{array}{c}3.0 \\
(0.2)\end{array}$ & $\begin{array}{c}3.1 \\
(0.3)\end{array}$ & $\begin{array}{c}0.4 \\
(<0.1)\end{array}$ & $\begin{array}{c}0.1 \\
(0.1)\end{array}$ & $\begin{array}{c}\mathbf{0 . 2} \\
(<0.1)\end{array}$ & $\begin{array}{c}0.1 \\
(0.1)\end{array}$ & $\begin{array}{c}1.2 \\
(<0.1)\end{array}$ & $\begin{array}{c}0.6 \\
(0.6)\end{array}$ & $\begin{array}{c}1.9 \\
(<0.1)\end{array}$ & $\begin{array}{c}0.5 \\
(0.8)\end{array}$ \\
\hline G0 & & 0.2 & 0.2 & 0.3 & 0.3 & 1.1 & 1.0 & 1.2 & 0.9 & 0.8 & 1.3 \\
\hline $\begin{array}{l}{[\mathrm{H} 3 \mathrm{~N} 4]} \\
\mathrm{G} 1\end{array}$ & & $\begin{array}{c}(<0.1) \\
0.3\end{array}$ & $\begin{array}{c}(0.2) \\
0.6\end{array}$ & $\begin{array}{c}(<0.1) \\
0.4\end{array}$ & $\begin{array}{c}(0.1) \\
0.3\end{array}$ & $\begin{array}{c}(<0.1) \\
\mathbf{0 . 2}\end{array}$ & $\begin{array}{c}(0.3) \\
0.6\end{array}$ & $\begin{array}{c}(<0.1) \\
0.2\end{array}$ & $\begin{array}{l}(0.5) \\
0.5\end{array}$ & $\begin{array}{c}(<0.1) \\
0.3\end{array}$ & $\begin{array}{c}(0.3) \\
1.2\end{array}$ \\
\hline [H4N4] & & $(<0.1)$ & $(0.2)$ & $(<0.1)$ & $(0.1)$ & $(<0.1)$ & $(0.2)$ & $(<0.1)$ & $(0.4)$ & $(<0.1)$ & $(0.3)$ \\
\hline $\begin{array}{l}\text { G2 } \\
{[\mathrm{H} 5 \mathrm{~N} 4]}\end{array}$ & & $\begin{array}{c}1.2 \\
(0.1)\end{array}$ & n.d. & $\begin{array}{c}0.4 \\
(<0.1)\end{array}$ & $\begin{array}{c}0.1 \\
(<0.1)\end{array}$ & $\begin{array}{c}0.2 \\
(<0.1)\end{array}$ & $\begin{array}{c}0.2 \\
(0.2)\end{array}$ & $\begin{array}{c}\mathbf{0 . 4} \\
(<0.1)\end{array}$ & n.d. & n.d. & n.d. \\
\hline $\begin{array}{l}\text { GO-N } \\
\text { [H3N3] }\end{array}$ & & $\begin{array}{c}0.7 \\
(0.2)\end{array}$ & $\begin{array}{c}0.8 \\
(0.2)\end{array}$ & $\begin{array}{c}0.4 \\
(<0.1)\end{array}$ & $\begin{array}{c}0.5 \\
(0.1)\end{array}$ & n.d. & n.d. & $\begin{array}{c}\mathbf{0 . 2} \\
(<0.1)\end{array}$ & $\begin{array}{c}0.1 \\
(0.1)\end{array}$ & $\begin{array}{c}0.3 \\
(<0.1)\end{array}$ & $\begin{array}{c}0.4 \\
(0.3)\end{array}$ \\
\hline $\begin{array}{l}\text { G1-N } \\
{[\mathrm{H} 4 \mathrm{~N} 3]}\end{array}$ & & n.d. & n.d. & n.d. & $\begin{array}{c}0.1 \\
(0.2)\end{array}$ & n.d. & n.d. & n.d. & n.d. & n.d. & n.d. \\
\hline $\begin{array}{l}\text { G1FS-N } \\
\text { [H4N3FS1] }\end{array}$ & & $\begin{array}{c}0.5 \\
(<0.1)\end{array}$ & $\begin{array}{c}0.6 \\
(0.2)\end{array}$ & $\begin{array}{c}0.3 \\
(<0.1)\end{array}$ & $\begin{array}{c}0.2 \\
(<0.1)\end{array}$ & n.d. & n.d. & n.d. & n.d. & n.d. & n.d. \\
\hline $\begin{array}{l}\text { G1FS } \\
\text { [H4N4FS1] }\end{array}$ & & $\begin{array}{c}\mathbf{0 . 2} \\
(<0.1)\end{array}$ & $\begin{array}{c}0.1 \\
(0.1)\end{array}$ & $\begin{array}{c}\mathbf{1 . 4} \\
(<0.1)\end{array}$ & $\begin{array}{c}1.5 \\
(0.2)\end{array}$ & n.d. & n.d. & n.d. & n.d. & n.d. & n.d. \\
\hline $\begin{array}{l}\text { M5 } \\
{[\mathrm{H} 5 \mathrm{~N} 2]}\end{array}$ & & $\begin{array}{c}3.4 \\
(0.5)\end{array}$ & $\begin{array}{c}3.8 \\
(0.5)\end{array}$ & $\begin{array}{c}0.9 \\
(<0.1)\end{array}$ & $\begin{array}{c}0.9 \\
(0.1)\end{array}$ & $\begin{array}{c}1.2 \\
(<0.1)\end{array}$ & $\begin{array}{c}0.7 \\
(0.2)\end{array}$ & $\begin{array}{c}1.5 \\
(<0.1)\end{array}$ & $\begin{array}{l}1.9 \\
(0.4)\end{array}$ & $\begin{array}{c}5.6 \\
(<0.1)\end{array}$ & $\begin{array}{c}7.9 \\
(0.8)\end{array}$ \\
\hline $\begin{array}{l}\text { M6 } \\
{[\mathrm{H} 6 \mathrm{~N} 2]}\end{array}$ & & $\begin{array}{c}0.2 \\
(<0.1) \\
\end{array}$ & n.d. & n.d. & n.d. & $\begin{array}{c}0.3 \\
(<0.1) \\
\end{array}$ & $\begin{array}{c}0.2 \\
(0.2) \\
\end{array}$ & $\begin{array}{c}0.5 \\
(<0.1) \\
\end{array}$ & $\begin{array}{c}0.1 \\
(0.1)\end{array}$ & $\begin{array}{c}1.5 \\
(<0.1) \\
\end{array}$ & $\begin{array}{r}2.3 \\
(0.5) \\
\end{array}$ \\
\hline
\end{tabular}


386

\begin{tabular}{|c|c|c|c|c|c|c|}
\hline $\begin{array}{l}\text { Glycan } \\
\text { Species }\end{array}$ & $\begin{array}{c}\text { Structural } \\
\text { Scheme }\end{array}$ & Theo M & 2-AB M & $z=1(+)$ & $z=2(+)$ & $z=3(+)$ \\
\hline $\begin{array}{l}\text { G0F } \\
\text { [H3N4F1] }\end{array}$ & & 1444.534 & 1582.750 & 1583.757 & 792.382 & 528.590 \\
\hline $\begin{array}{l}\text { G1F } \\
\text { [H4N4F1] }\end{array}$ & & 1606.587 & 1744.803 & 1745.810 & 873.409 & 582.608 \\
\hline $\begin{array}{l}\text { G2F } \\
\text { [H5N4F1] }\end{array}$ & & 1768.640 & 1906.856 & 1907.863 & 954.435 & 636.626 \\
\hline $\begin{array}{l}\text { GOF-N } \\
\text { [H3N3F1] }\end{array}$ & & 1241.455 & 1379.671 & 1380.678 & 690.843 & 460.897 \\
\hline $\begin{array}{l}\text { G1F-N } \\
\text { [H4N3F1] }\end{array}$ & & 1403.507 & 1541.723 & 1542.730 & 771.869 & 514.915 \\
\hline $\begin{array}{l}\text { G0 } \\
{[\mathrm{H} 3 \mathrm{~N} 4]}\end{array}$ & & 1298.476 & 1436.692 & 1437.699 & 719.353 & 479.904 \\
\hline $\begin{array}{l}\text { G1 } \\
{[\mathrm{H} 4 \mathrm{~N} 4]}\end{array}$ & & 1460.529 & 1598.754 & 1599.752 & 800.380 & 533.922 \\
\hline $\begin{array}{l}\text { G2 } \\
{[\mathrm{H} 5 \mathrm{~N} 4]}\end{array}$ & & 1622.582 & 1760.798 & 1761.805 & 881.406 & 587.940 \\
\hline $\begin{array}{l}\text { GO-N } \\
\text { [H3N3] }\end{array}$ & & 1095.397 & 1233.613 & 1234.620 & 617.814 & 412.211 \\
\hline $\begin{array}{l}\text { G1-N } \\
\text { [H4N3] }\end{array}$ & & 1257.449 & 1395.665 & 1396.672 & 698.840 & 466.229 \\
\hline $\begin{array}{l}\text { G1FS-N } \\
\text { [H4N3FS1] }\end{array}$ & & 1710.598 & 1848.814 & 1849.821 & 925.414 & 617.178 \\
\hline $\begin{array}{l}\text { G1FS } \\
\text { [H4N4FS1] }\end{array}$ & & 1913.677 & 2051.893 & 2052.900 & 1026.954 & 684.971 \\
\hline $\begin{array}{l}\text { M5 } \\
{[\mathrm{H} 5 \mathrm{~N} 2]}\end{array}$ & & 1216.423 & 1354.639 & 1355.646 & 678.327 & 452.553 \\
\hline $\begin{array}{l}\mathrm{M} 6 \\
{[\mathrm{H} 6 \mathrm{~N} 2]}\end{array}$ & & 1378.476 & 1516.692 & 1517.699 & 759.353 & 506.571 \\
\hline
\end{tabular}

